\title{
APPLICATION OF THE FIFTH AMENDIMENT PRIVILEGE AGAINST SELF-INCRIMINATION TO THE CIVIL COMIMITIMENT PROCEEDING
}

Each year almost one-half million persons are admitted to state and county mental hospitals in the United States; ${ }^{1}$ of these, a substantial majority are involuntarily committed. ${ }^{2}$ The courts have been reluctant to deal with the issues imvolved in involuntary hospitalizations. The reason most frequently advanced for this judicial reluctance is that such proceedings are "civil" in nature and therefore do not activate the panoply of constitutional safeguards which accompany a "criminal" proceeding. ${ }^{3}$ Although involuntary commitment proceedings are ostensibly mitiated for the benefit of the individual, ${ }^{4}$ they may lead to incarceration in an institution where treatment is mcreasingly recognized as woefully madequate. ${ }^{5}$ Since the number of people currently in inental hospitals greatly exceeds the number in penal institutions, ${ }^{6}$ the invol-

1. H. Bethel \& R. Redick, Provisional Patient Movement and Administrative Data, State and County Mental Hospital Inpatient Services, July 1, I970-June 30, 1971, Statistical Note 60, Survey and Reports Section, National Institute of Mental Health, at 2 (1972).

HEREINAFTER THE FOLLOWING CITATIONS WILL BE USED IN THIS NOTE:

Leifer, The Competence of the Psychiatrist to Assist in the Determination of Incompetency: A Skeptical Inquiry into the Courtroom Function of Psychiatrists, 14 SYRACUSE L. Rev. 564 (1963) [hereinafter cited as Leifer];

Note, Requiring a Criminal Defendant to Submit to a Government Psychiatric Examination: On Invasion of the Privilege Against Self-Incrimination, 83 HARv. L. REv. 648 (1970) [hereinafter cited as Note, Requiring a Criminal Defendant].

2. The Mentally Disabled and the Law 17 (rev. ed. S. Brakel \& R. Rock 1971). See also Hearings on Constitutional Rights of the Mentally Ill Before the Subcomm. on Constitutional Rights of the Senate Judiciary Comm., 87th Cong., 1st Sess., pt. 1, at ii, 43 (1961).

3. See, e.g., Sorter v. Austen, 221 Ala. 481, 129 So. 51 (1930); Sporza v. German Sav. Bank, 192 N.Y. 8, 84 N.E. 406 (1908). This distinction has not, however, been universally accepted. See, e.g., Reade v. Halpin, 193 App. Div. 566, 569, 184 N.Y.S. 438, 439-40 (3d Dep't 1920); uotes 16-18 infra and accompanying text. See generally Note, Hospitalization of the Mentally Ill: Due Process and Equal Protection, 35 BROOKLYN L. REv. 187, 198-202 (1969); Note, Civil Restraint, Mental Illness, and the Right to Treatment, 77 YALE L.J. 87, 89 (1967).

4. See notes 19-25 infra and accompanying text.

5. See notes 26-27 infra and accompanying text.

6. In $\mathbf{1 9 7 0}$ the resident penal population for federal and state prisons approached 
untary hospitalization process warrants close scrutiny to determine whether it is in accord with fundamental constitutional safeguards. ${ }^{7}$ This Note will therefore first examine the applicability of the basic constitutional guarantee that no person shall be deprived of his liberty without due process of law to the involuntary hospitalization or "civil" commitment proceeding. ${ }^{8}$ Because the medical expert exerts enormous influence over the decision to commit an individual, both the precise nature of his role in the commitunent process and his ability to perform that function will be outlined. Finally, the fact that the medical expert's function is currently centered upon a psychiatric interview with the individual subjected to the commitment proceeding necessitates a determination of the extent to which the subject may avoid such an examination by invoking the safeguards of the fifth amendment. ${ }^{\circ}$

\section{Involuntary "Civil" Commitment and Due Process of Law}

The decision as to whether an individual is to be committed may be made by a court, an administrative tribunal, or a panel of physicians. ${ }^{10}$ Regardless of the nature of the committing body, due process requires that when there is a danger of deprivation of life, liberty or property there must exist "that kind of procedure . . . which is suitable and proper to the nature of the case." 11 At a minimum, this means that every person must liave a fair hearing, with notice, if lie is threatened with civil commitment. ${ }^{12}$ Beyond this basic guarantee of a fair hearing, there is a significant dilution of constitutional protections.

200,000. 1972 Statistical Abstract of the United States 161. This compares with a resident patient population for meutal hospitals of 338,000 in the same year. 1970 National Institute of Health Statistics, reprinted in 1973 WorLd ALMandC 961. See also Statement of Senator Alexander Wiley, 1961 Hearings, supra note 2, at 11.

7. See generally Chambers, Alternatives to Civil Commitment of the Mentally Ill: Practical Guides and Constitutional Imperatives, 70 Mich. L. REV. 1107 (1972); Symposium, Lawyers and Psychiatrists in the Court: Issues on Civil Commitment, 32 MD. L. REv. 3 (1972); Symposium, The Legal Rights of the Mentally Retarded, 23 SYRACUSE L. REv. 991 (1972); Note, Alcoholics and the Mentally Ill: Their Institutionalization and De-institutionalization, 7 ReAL PROPERTY PROB. \& TRIAL J. 532 (1972); Note, Involuntary Civil Commitment-A Constitutional Right to Treatment, 23 Syracuse L. Rev. 125 (1972); Note, Wyatt v. Stickney-A Constitutional Right to Treatment for the Mentally Ill, 34 U. PITT. L. REv. 79 (1972).

8. See U.S. CONST. amends. V \& XTV.

9. U.S. CoNsT. amend. V.

10. F. Lindman \& D. McIntyre, The Mentally Disabled and the LaW 16-17 (1961).

11. Ex parte Wall, 107 U.S. 265,289 (1883). See also Hagar v. Rcclamation Dist., 111 U.S. 701, 708 (1884); Hurtado v. California, 110 U.S. 516, 537 (1884).

12. See Simon v. Craft, 182 U.S. 427, 437 (1901). See also Mullane v. Central Hanover Bank \& Trust Co., 339 U.S. 306 (1950); Chaloner v. Sherman, 242 U.S. 455 (1917). But see Fhagen v. Miller, 357 Misc. 2d 163, 317 N.Y.S.2d 128 (Sup. Ct. 
The most persistent justification for the relaxation of constitutional safeguards in this area has been that an involuntary hospitalization proceeding-because of its "civil" character-requires a lesser degree of constitutional protection than does a "criminal" proceeding. ${ }^{13}$ Thus, in Robinson v. California ${ }^{14}$ the Supreme Court suggested that a state might appropriately commit a mentally ill individual through a "civil" proceeding. ${ }^{15}$ Based on the tacit recognition in Robinson of the importance of the "civil" or "criminal" label, it may be argued that the constitutionality of current involuntary hospitalization procedures should be measured against the relaxed standards needed to satisfy due process in "civil" proceedings. However, this implied recognition of the significance of the label attached to a proceeding was seriously undermined in In re Gault, ${ }^{16}$ where the Supreme Court applied broad constitutional safeguards to juvenile proceedings; in so doing, the Court rejected the application of the "civil" label as dispositive of the measure of constitutional rights to be afforded the individual. ${ }^{17}$ Thus, the relevant inquiry after Gault is directed to the substance and not the form of the proceedings. ${ }^{18}$

The second justification for involuntary commitment without full constitutional protections may be described as the "beneficent theory of state action." The essence of this approach is that, since the motives of the state are beneficent and lave as their objective the treatment of

1970) (due process is not offended by a temporary confimement, without prior notice or hearing, if immediate action is necessary for the protection of society or the welfare of the individual). Procedures in which the patient is given neither notice nor hearing until after hospitalization have been upheld. See, e.g., Sporza v. Gernan Sav. Bank, 192 N.Y. 8, 84 N.E. 406 (1908). Contra, State ex rel. Fuller v. Mullmax, 364 Mo. 858, 269 S.W.2d 72 (1954). It has been noted that such hearings are frequently couducted at the hospital while the patient is under the influence of his treatment, a procedure that should be condoned only if the person poses an immediate threat to himself or others. See Note, Civil Commitment of the Mentally Ill: Theories and Procedures, 79 HaRv. L. REv. 1288, 1292 (1966). When the hearing is deferred until after commitment, the patient is likely to have considerable difficulty in asserting his rights. See Comment, The New Mental Health Codes: Safeguards in Compulsory Commitment and Release, 61 Nw. U.L. Rev. 977, 980 (1967).

13. See note 3 supra and accompanying text.

14. 370 U.S. 660 (1962) (dictum).

15. Id. at 666. See also Note, supra note 12, at 1291.

16. 387 U.S. 1 (1967).

17. Id. at $49-50$.

18. Gault may be narrowly read to rest primarily on the similarity of the consequences which may flow from the juvemile proceeding to those of the adult criminal proceeding. In each case, the offender is threatened with incarceration in a penaltype institution. See Note, Requiring a Criminal Defendant 662. However, the Supreme Court has not confined Gault to its facts. See Specht v. Patterson, 386 U.S. 605, 608 (1967). 
the individual, excessive preoccupation with legal safeguards may frustrate the legitimate state interest in the mental health of its citizens. ${ }^{10}$ Essential to this justification is the premise that mental health laws are motivated by a philosophy substantially different from that which shapes the criminal laws; ${ }^{20}$ imsofar as the traditional criminal law objectives of deterrence and retribution are not present in the civil commitinent proceeding, the state clearly assumes a less antagonistic posture toward the individual. ${ }^{21}$ For this reason, certain procedural protections traditionally associated with the criminal prosecution may appear superfluous when applied to the imvoluntary hospitalization proceeding. ${ }^{22}$ Furthermore, rigid adherence to legal safeguards may not only undermine the treatment of the individual, but may actually do him positive harm. ${ }^{23}$ This argument recognizes the existence of "medical"- as opposed to "legal"-rights" and views commitment primarily as a medical decision. ${ }^{25}$

19. See Note, Hospitalization of the Mentally Ill, supra note 3, at 198; Note, Civil Restraint, supra note 3, at 88. For an articulate expression of concern that formalistic legal procedures may obstruct the treatment of an imdividual, see the statement of Dr. Zigmond M. Lebensohn, Hearings on Constitutional Rights of the Mentally Ill Before the Subcomm. on Constitutional Rights of the Senate Judiciary Comm., 91st Cong., 2d Sess. 25-26 (1970).

20. Kittrie, Compulsory Mental Treatment and the Requirements of "Due Process," 21 Oнго Sr. L. REv. 28, 51 (1960).

21. Correction, deterrence, reform, and retribution are frequently listed as the principal objectives of imprisonment. See generally L. WeINREB, Crnminal LaW 437-57 (1969).

22. The jury has been attacked as being the "legal safeguard most exemplary of excessive legalism in the commitment process." Comment, Analysis of Legal and Medical Considerations in Commitment of the Mentally Ill, 56 YALE L.J. 1178, 1192 (1947).

23. See Crawfis, Civil Rights and Mental Hospital Administration, 9 Clev.-MAr.

L. REv. 417 (1960). The author observes:

It is certainly in accordance with good legal principles that a person, whose legal rights are being adjudicated, has a right to defend himself. However, for many patients, particularly the paranoid individual, the testimony of relatives or friends or physicians concerning his symptoms may only further convince him that he is being persecuted and that everyone is against him. Thus, it is not surprising that the patient comes to beheve that the staff of the hospital are participants in this plot, and for this reason he is unable and unwilling to cooperate and to participate in the process of diagnosis and treatment. Id. at 419.

See also Ross, Commitment of the Mentally Ill: Problems of Law and Policy, 57 Mich. L. REv. 945, 966 (1959). While this argument identifies a significant problem, it begs the essential question since it assumes that the individual is mentally ill.

24. See 1961 Hearings, supra note 2, at 80-81.

25. It has been argned that prime authority during the initial stages of the commitment process should therefore lie in the hands of a physician. Comment, supra note 22. Furthermore, it is often suggested that minimizing the legal requirements may serve a desirable therapeutic function by convincing the individual he is being treated rather than punished. Note, Constitutionality of Nonjudicial Confinement, 3 STaN. L. Rev. $109,110(1950)$. 
The "beneficent theory of state action," however, has come under increasing attack. The principal objection goes to the nature of the treatment received by persons in mental institutions, and implies that civil commitment may amount to a life sentence in an institution markedly similar to a prison. ${ }^{26}$ Critics of the theory contend that mental institutions serve a primarily custodial function and that claims of successful treatment are often illusory. ${ }^{27}$ To the extent that the individual fails to receive treatment after he has been committed, the "beneficent theory of state action" is invalid.

Several courts have suggested that the full range of procedural safeguards formerly reserved to criminal cases might be constitutionally required when inadequacy of treatment is demonstrated. ${ }^{28}$ Furthermore, it has been argued that any deprivation of liberty should automatically trigger these greater constitutional protections. ${ }^{29}$ While neither

26. See Szasz, Psychiatry, Ethics, and the Criminal Law, 58 CoLum. L. Rev. 183, 196 (1958); Note, Requiring a Criminal Defendant 662; Note, Civil Restraint, supra note 3 , at 98 . The petitioner must generally prove he is sane in order to obtain his release. See cases cited in Comment, Due Process for All-Constitutional Standards for Involuntary Civil Commitment and Release, 34 U. CHr. L. Rev. 633, 635 n.7 (1967). For a general discussion of the similarities between mental hospitals and prisons, see E. Goffman, Asyiums: Essays in the Soclal Situation of Mental PaTIENTS AND OTHER INMATES (1961). When the individual is committed he may lose his right to vote and his right to enter contracts. See F. LINDMAN \& D. McINTYRE, supra note 10, at 263-97; T. SZASZ, LAW, LIBERTY AND PsYCHIATRY 40-41 (1969).

27. For a severe indictment of one state's mental institutions, see Wyatt v. Stickney, 325 F. Supp. 781, 785 (M.D. Ala. 1971), where the court stated:

There can be no legal (or moral) justification for the State of Alabama's failing to afford treatment-and adequate treatment from a medical standpoint - to the ... patients who have been civilly committed ... for treatment purposes. To deprive any citizen of his or her liberty upon the altruistic theory that the confineinent is for humane therapeutic reasons and then fail to provide adequate treatment violates the very fundainentals of due process. Although Alabama ranks fiftieth among the states in per-patient expenditures per day, id. at 784, the American Psychiatric Association has suggested that every public mental institution in the Umited States is "inadequately" staffed. See Rouse v. Cameron, 373 F.2d 451, 458 (D.C. Cir. 1966). See also Note, Involuntary Civil Commitment, supra note 7, at 136; Note, Civil Restraint, supra note 3, at 88.

28. People v. Fuller, 24 N.Y.2d 292, 302-03, 300 N.Y.S.2d 102, 107-08 (1969) (civil commitment of narcotics addict):

If compulsory coinunitment turns out in fact to be a veneer for an extended jail term and is not a fully developed, comprehensive and effective scheme, it will have lost its claim to be a project devoted solely to curative ends. It will then take on the characteristics of [a] normal jail sentence, with a side order of help. The moment that the program begins to serve the traditional purposes of criminal punishment, such as deterrence, preventive detention, or retribution, then the extended demial of liberty is simply no different from a prison sentence and the constitutional guarantees applicable to criminal proceedings will apply in full measure.

See also Rouse v. Cameron, 373 F.2d 451, 453 n.9 (D.C. Cir. 1966); Wyatt v. Stickney, 325 F. Supp. 781, 784 (M.D. Ala. 1971); Note, Civil Restraint, supra note 3, at $87-92$.

29. See, e.g., Ennis, Civil Liberties and Mental Illness, 7 Crim. L. Bull. 101 
of these broad propositions has been accepted by the courts, ${ }^{30}$ it is clear that, at a minimum, the label attached to a proceeding is no longer dispositive of the extent to which constitutional safeguards are required in that proceeding. ${ }^{31}$ It is also clear that as institutional treatment becomes more obviously inadequate, the involuntary commitment proceeding increasingly reseinbles a traditional criminal proceeding; therefore the subject of the hearing inay be entitled to an increasing degree of constitutional protection.

\section{The Role of the Medical Expert and the Psychitric INTERVIEW IN Civil COMMITMENT}

The growth in the power and prestige of psychiatry and the role of the medical expert in the civil commitment proceeding has been marked in recent years, ${ }^{32}$ yet relatively few checks have been developed to regulate this expanding influence and ensure the accuracy of medical testimony. Given this essentially unregulated role, questions arise as to whether the current influence of the medical expert ${ }^{33}$ and the use of

(1971). Under this view, the effectiveness of the treatment is not relevant when the issue is the deprivation of an individual's liberty; certainly incarceration, whether in a prison, juvenile detention home or mental hospital, involves such a deprivation of liberty. As one court has noted, "[n]o matter how sweetly disguised or delicate the language, involuntary confinement is a loss of freedoun." Application of Neisloss, 8 Misc. 2d 912, 913, 171 N.Y.S.2d 875, 876 (West Co. Ct. 1957).

At least one high state tribunal, in rejecting both the labeling process and the "beneficent theory of state action," has held that the rules governing commitunent should be the same in a "civil" as in a criminal proceeding. Denton v. Commonwealth, 383 S.W.2d 681 (Ky. Ct. App. 1964). The court observed that:

[W] hen a proceeding may lead to the loss of personal liberty, the defendant in that proceeding should be afforded the same coustitutional protection as is given to the accused in a criminal prosecution. Id. at 682 .

It has even been suggested that the mentally ill individual may be in need of more extensive procedural protections than the criminal defendant since he is less likely to understand the nature and consequences of the proceedings against him. F. LINDMAN $\&$ D. MCINTYRE, supra note 10 , at 29.

30. See People v. Studdard, 51 Ill. 2d 190, 281 N.E.2d 678 (1972); note 3 supra.

31. See notes 16-18 supra aud accompanying text.

32. See Leifer 564 . In reaction to the recent marked growth in the power and prestige of the medical expert in the commitment proceeding, one commentator observed: "[T]here are two basic ways in which a person may be penalized in our present society. One is by running afoul of the law. The other is by running afoul of psychiatrists." Szasz, Civil Liberties and the Mentally Ill, 9 Clev.-Mar. L. Rev. 399, 406-07 (1960).

33. Within the context of this Note, the term "medical expert" is used to signify a person qualified under the laws of a particular jurisdiction to conduct a mental examination of an individual and report on his findings to a court. In practice, any liceused physician is usually statutorily qualified to conduct such an examination. See, e.g., N.Y. Mental Hygiene LaW $\S \S 2(18), 124$ (McKinney Supp. 1970) (licensed 
his principal diagnostic tool-the psychiatric interview-may constitute a violation of the subject's fifth amendment rights.

\section{The Influence of the Medical Expert in the Civil Commitment Proceed- ing}

To a considerable degree, the importance of the medical expert in the involuntary hospitalization proceeding may be attributed to the methods of psychiatric analysis and technique. Attorneys, judges and juries are often confused and bewildered by the testimony of the medical expert. ${ }^{34}$ Because civil commitment is a "non-adversary" proceeding, ${ }^{35}$ experts play the dominant role, and what constitutes "success" for

physician in practice for three years); OHro Rev. Code ANN. $\$ \S 5122.01,5122.14$ (Page 1970) (individual licensed to practice medicine in the state); Tex. Rev. Crv. ST. ANN., at arts. 5547-4, -32 (Vernon 1958) (individual licensed to practice medicine in the state); WASH. REv. CODE ANN. $\$ \S 71.02 .010,71.02 .170$ (1962) (individual liceused to practice medicine in the state).

Since most physicians are unfamiliar with mental illness and psychotic behavior, yet qualify as "experts," it seems anamolous not to qualify the clinical psychologist as an examiner. In criminal cases it is clear that the competence of an individual to diagnose and testify as to mental disorders "does not depend on his claim to the title of psychologist or psychiatrist." Umited States v. Riggleman, 411 F.2d 1190, 1191 (4th Cir. 1969). See also Jenkins v. United States, 307 F.2d 637 (D.C. Cir. 1962); Hidden v. Mutual Life Ins. Co., 217 F.2d 818, 820 (4th Cir. 1954); Sandow v. Weyerhaeuser Co., 252 Ore. 377, 449 P.2d 426 (1969); People v. Pennington, 66 Cal. 2d 508, 426 P.2d 942, 58 Cal. Rptr. 374 (1967). Psychologists have been qualified as experts in proceedings to release persons who previously had been civilly committed. See In re Masters, 216 Minn. 553, 13 N.W.2d 487 (1944). Furthermore, many experts argue that mental disorders and their diagnosis are not "medical" probleins at all, but rather "behavioral" problems. See, e.g., Reese v. Naylor, 222 So. 2d 487, 489 (Fla. 1969). See generally J. Coleman, ABnormal Psychology and MODERN LIFE 14-22 (3d ed. 1964); Levitt, The Psychologist: A Neglected Legal Resource, 45 Ind. L.J. 82 (1969).

The more modern and entightened "civil" commitment statutes do qualify psychologists as competent to perform the mental examination. See Cat. WeLf. \& INST'NS CODE $\$ \$ 5251,6507$ (West 1972). Significantly, in other areas legislatures and courts have been unable to distinguish between psychiatrists and psychologists in terms of their dealing with the mentally ill. Thus many states recognize a "psychotherapistpatient" privilege for communications made to certified meinbers of either profession. See CAL. Evid. Code $\$ 1010$ (West 1972). See also FED. R. EvID. 504(a)(2) (proposed). In addition, several states have long recognized a psychologist-patient privilege, and have only very recently adopted a more restricted psychiatrist-patient privilege. Compare Ky. Rev. Stat. ANn. \& 319.11 (1972) and Tenn. Code Ann. § 631117 (1955) with Ky. Rev. Stat. Ann. $\$ 421.215$ (1972) and Tenn. Code AnN. $\S 24-112$ (1972).

34. For an excellent examination of the role and function of the attorney in the commitment of the mentally ill, see Cohen, The Function of the Attorney in the Commitment of the Mentally Ill, 44 Tex. L. Rev. 424 (1966).

35. Id. at 448. See also Comment, The New Mental Health Codes: Safeguards in Compulsory Commitment and Release, 61 Nw. U.L. Rev. 977, 981 (1967). 
the attorney is neither clearly defined nor readily ascertainable. ${ }^{30}$ As a result, counsel frequently adopts a deferential attitude toward the medical expert and performs merely a ceremonial function in the proceeding. ${ }^{37}$ The court is seldom less confused than counsel-one judge has described the judicial reliance upon expert testimony as follows:

[W] are guided almost 100 percent by what the medical examiners testify to. I find my role with respect to that is mostly relegated to a discussion with the medical examiner as to various possibitities that might be available for the patient that they consider to be mentally ill. I hardly conceive of myself, as putting myself up as a better medical expert than the examiners and saying "You think this man is mentally ill but I don't."'38

Judicial deference to the medical expert may be even more extreme in those jurisdictions where involuntary hospitalization is largely based on the certification of one or more physicians. In these situations the task of the judge is frequently reduced to verifying the accuracy of the physicians' signatures. $^{39}$ Given the passive role currently played by courts and counsel in the proceeding, the quality of the psychiatric testimony assumes critical importance.

The medical expert's status as an expert witness is based upon the assumption that his "scientific" credentials enable him to effectively evaluate and explain human behavior. ${ }^{40}$ However, the essence of a science is the objectivity of its investigations and conclusions; to the extent that a psychiatric diagnosis is a subjective determination, ${ }^{41}$ the scientific status attributed to psychiatry by the courts is undermined. ${ }^{42}$

36. Cohen, supra note 34 , at 448.

37. See id. at 450 (citations omitted):

Nearly every attorney interviewed in connection with this article took a position of deference to the psychiatric opinion. "We have no choice but to trust the psychiatrist." "The hospital has an unlimited number of doctors available to overwlielm any contentions raised by one who is, after all, unfamiliar with psychiatry." This, of course, is in sharp contrast to the situation when the lawyer feels "something is at stake." The encounters between lawyers and psycliatrists during an insanity defense or a will contest involving substantial assets are hardly deferential.

38. Testimony of Judge Reppy before the California Senate Fact Finding Comm. on Judiciary, Admission Care and Treatment 13 (1965), cited in Project, Civil Commitment of the Mentally Ill, 14 U.C.L.A.L. REv. 822, 860 n.207 (1967) (emphasis added).

39. F. LINDMAN \& D. MCINTYRE, supra note 10, at 33.

40. See Leifer 566.

41. Most persons currently in mental hospitals are said to be suffering from schizophrenia-a nental disease diagnosed entirely by means of subjective interpretations of human behavior. 1970 Hearings, supra note 19, at 418 (statement of James S. Turner and Robert Carr). Cf. Leifer 570-71.

42. It has been noted that the courts are themselves accustomed to and capable of nuaking subjective as opposed to scientific determinations. Leifer 570-71. 
Moreover, regardless of psychiatry's scientific status, the medical expert may be performing a paralegal rather than a medical or scientific function in evaluating human behavior and the need for treatment in the context of commitment proceedings. ${ }^{43}$

Critics of the scientific status ascribed to psychiatry have noted that the psychiatrist is able to disguise the limitations of his science by translating the information which he compiles into a diagnosis replete with techmical jargon, thereby giving a spurious appearance of scientific and medical authenticity. ${ }^{44}$ Undue weight may thus be given medical testimony because of the apparently technical nature of the information which it contains. ${ }^{45}$ The mevitable conclusion of the proponents of this argument is that the medical expert's role in the civil commitment proceeding should be much more narrowly defimed. Alternatively, the influence of the medical expert could be tempered by the increased participation of both the bench and bar. ${ }^{46}$ Even if his role were so tempered or redefined, however, it seems highly unlikely that the medical expert's testimony would cease to have a significant effect on the outcome of the civil commitment proceeding. ${ }^{47}$ Thus, it becomes

This line of argument suggests that the psychiatrist's claim to expertise-his medical training-may be irrelevant in the determination of incompetency or the need for hospitalization. Id. at 572; cf. Levitt, supra note 33, at 83.

43. Leifer 569; Project, supra note 38, at 860.

44. Leifer 574.

45. See Note, Requiring a Criminal Defendant 660.

46. See, e.g., Cohen, supra note 34. For example, a prepared and confident counsel, rather than adopting a deferential attitude toward the medical expert, should be in a position to cross-examine vigorously the medical expert in a manner similar to the one he employs in an adversary proceeding.

The medical expert should also be required by the court to avoid the simple expedient of labeling a mental disorder and instead direct himself to an analysis of the individual's mental processes, including an adequate description of how he arrived at his conclusions. See Salzman, Psychiatric Interviews as Evidence: The Role of the Psychiatrist in Court-Some Suggestions and Case Histories, 30 GEO. WASHr. L. REv. 853, 859-60 (1962). See also Rollerson v. United States, 343 F.2d 269 (D.C. Cir. 1964); Carter v. United States, 252 F.2d 608, 617 (D.C. Cir. 1957):

Description and explanation of the origin, developinent and inanifestations of the alleged disease are the chief functions of the expert witness. The chief value of an expert's testimony in this field ... rests upon the material from which his opinion is fashioned and the reasoning by which he progresses from his material to his conclusion; in the explanation of the disease and its dynamics, that is, how it occurred, developed, and affected the mental and emotional processes of the defendant; it does not lie in his mere expression of conclusion. The ultimate inferences vel non of relationship, of cause and effect, are for the trier of the facts.

See generally Guttmacher \& Weihofen, The Psychiatrist on the Witness Stand, 32 Boston U.L. REv. 287 (1952); Rheingold, The Basis of Medical Testimony, 15 VAND.

L. Rev. 473 (1962).

47. See notes 34-41 infra and accompanying text. 
necessary to examine the medical expert's principal diagnostic toolthe psychiatric interview.

\section{The Psychiatric Interview}

Little special training is needed to recognize the obvious mental disorder-a layman is usually able to identify the severely disturbed person. ${ }^{48}$ The difficulties in diagnosis exist in identifying disguised mental disorders and those irregularities which affect only a limited aspect of the individual's behavior. ${ }^{40} \mathrm{~A}$ diagnosis of this nature requires a somewhat extensive examination of the patient; ${ }^{50}$ under such circumstances, the interview remains the basic diagnostic tool of the medical expert. ${ }^{51}$ The object of this interview is to uncover and analyze the subject's personality. ${ }^{52}$ In so doing, the medical expert may unavoidably uncover feelings and attitudes which the individual does not wish to reveal to others. ${ }^{53}$ Hence, such an interview may not only have an enormous impact on the subject's future; it may also penetrate the essence of his personal privacy. ${ }^{54}$

\section{The Privilegge Against Self-Incrimination}

It has been established above that it is now necessary to go beyond "civil" and "criminal" labels in deciding whether to apply constitutional

48. Salzman, supra note 46 , at 857 .

49. Id.

50. As a general rule, a good doctor-patient relationship is a prerequisite to a successful examination, and this may require that the individual receive assurances that the results of the examination will not be used against him. Smith, Psychiatric Examinations in Federal Mental Competency Proceedings, 37 F.R.D. 171, 172 (1964).

51. See Rollerson v. United States, 343 F.2d 269, 274 (D.C. Cir. 1964); Krash, The Durham Rule and Judicial Administration of the Insanity Defense in the District of Columbia, 70 YALE L.J. 905,918 (1961).

52. See Diamond, Criminal Responsibility of the Mentaliy Ill, 14 STAN. L. REv. 59, 83 (1961). See generally Note, Requiring a Criminal Defendant 658.

53. See Note, Requiring a Criminal Defendant 658.

54. Although many of the criticisms pertaining to psychiatric interviews would apply as well to psychological testing, the psychologist's node of operation may mitigate some of these criticisms. Whereas psychiatrists regard deviant behavior merely as a symptom of the underlying "illness," psychologists focus on the behavior itself. Thus the psychologist is less likely to probe into the subject's family history, infantile development, or adolescent complexes; he therefore is less likely to intrude into the sanctity of the individnal's privacy. The psychologist also attempts to gain the confidence of the patient, but withont the deep transference relationship which is likely to be shattered when the psychiatrist testifies. Furthermore, the reasons for the psychological diagnosis, which is often based on projective testing and empirical data, may be more easily understood and thus subject to challenge and cross-examination than are conclusory psychiatric labels based on more subjective analysis. See Levitt, supra note 33, at 86 ; note 33 supra. 
safeguards. ${ }^{55}$ Furthermore, to the extent that the treatment received in mental mstitutions is madequate,$^{56}$ the consequences of the civil commitment proceeding resemble those of the traditional crimmal proceeding. Therefore, an increased degree of procedural protection may be constitutionally required..$^{57}$ Since the medical expert's interview plays a central role in the commitment proceeding the question arises as to whether the protection of the fifth amendment may be invoked to avoid the compelled submission to the psychiatric interview.

Partly because it may mean different things in different settings, there is no general consensus as to a single "policy" behind the privilege against self-incrimination ${ }^{68}$ Historically, the privilege was narrowly addressed to the right of an individual to remain silent whenever his own speech might reasonably lead to a criminal conviction. It was considered fundamentally unfair for the state to force an individual to aid in its attempt to deprive him of his liberty. ${ }^{59}$ In addition, modern courts and commentators have agreed that a second and broader function of the privilege ${ }^{60}$ is the recognition and protection of an area of privacy for the individual-a domain into which the state will not be allowed to intrude. ${ }^{01}$ Although emphasized by the courts only recently, the desire to maintain a proper balance between individual and governmental interests was a major factor in the adoption of the privilege. $^{62}$

55. See notes 16-18 supra and accompanying text.

56. See notes $26-27$ supra and accompanying text.

57. See notes 28-31 supra and accompanying text.

58. 8 J. WIGMORE, EVDENCE $\S 2551$, at 296 (McNaughton rev. 1961). U.S. Const. amend. V provides in part: "No person ... shall be compelled in any criminal case to be a witness against himself ..." (emphasis added). For an extensive examination of the history, policy, and application of the privilege against selfincrimination, see $8 \mathrm{~J}$. WIGMORE, supra, $\$ \S 2250-84$.

59. Forcing an individual to choose between self-preservation and the commission of another crime (perjury) was felt to violate a fundamental respect for human dignity. The early proponents of the privilege were also particularly concerned about the widespread use of physical torture to extract incriminating admissions froin suspects. C. MCCoRMick, HANDBOOK OF THE LAW OF EVIDENCE $\$ 118$, at 251 (2d ed. Cleary 1972).

60. For a listing of the various policies which have been suggested, see $8 \mathrm{~J}$. WIGMORE, supra note 58 , $\$ 2251$, at 310-18.

61. This has been described as a "right to a private enclave where [the individual] may lead a private life." Unitcd States v. Grunewald, 233 F.2d 556, 581-82 (2d Cir. 1956) (Frank, J., dissenting), rev'd, 353 U.S. 391 (1957). See also Tehan v. United States ex. rel. Shott, 382 U.S. 406, 416 (1966); Dann, The Fifth Amendment Privilege Against Self Incrimination: Extorting Physical Evidence from a Suspect, 43 So. CaL. L. Rev. 597, 611-30 (1970); Ratner, Consequences of Exercising the Privilege Against Self-Incrimination, 24 U. CHI. L. REv. 472, 484-87 (1957).

62. See Ratner, supra note 61 , at 484 . The fifth amendment does not stand 
The Supreme Court has never addressed itself to the issue of whether a mental examination conducted as part of a civil commitment proceeding is a proper forum for asserting the privilege; ${ }^{03}$ nor may the question be answered by reference to the pre-enactment history of the fifth amendment. ${ }^{64}$ Dean Wigmore's analysis of the availability of the privilege, ${ }^{65}$ which has to a considerable extent been adopted by the Supreme Court, ${ }^{60}$ distinguishes between nonprotected "real" evidence, such as blood tests, ${ }^{07}$ voice exemplars, ${ }^{08}$ and handwriting samples, ${ }^{69}$ and protected "testimonial" evidence, such as

alone in its protection of the individual from unwelcome intrusions by the state. See Dann, supra note 61, at 601:

The first amendment prevents the state from interfering with one's freedom to associate with whom he wishes; the third amendment himits the state's right to quarter soldiers in the homes of private citizens; the fourth amendment prevents unreasonable searches into one's person, home, or effects; and the fifth amendment prevents the state from extracting damaging information against the subject's will.

The author observes that, although there are a number of similarities between the fourth and fifth amendments, they differ in the type of evidence which they prohibit; the fonrth amendment speaks of "persons, houses, papers and effects," and would therefore appear to be limited largely to physical intrusions, while the fifth amendment seems to be more concerned with psychological privacy. Id. at 601-02. Cf. Griswold v. Connecticut, 381 U.S. 479, 482-85 (1965).

Indeed, it has been held that there exists "a zone of privacy created by several fundamental constitutional guarantees." Id. at 485 .

63. At least one state supreme court has, however, considered the question. The Illinois Supreme Court in People v. Keith, 38 III. 2d 405, 231 N.E.2d 387 (1967), held that the respondent in a "civil" commitment proceeding could not avoid taking the stand and testifying by invoking the privilege against self-incrimination. The court apparently did not conclude that the inadequacy of treatment facilities had made the involuntary hospitalization proceeding similar to a criminal proceeding, and instead adopted the rigid labeling approach rejected in In re Gault, 387 U.S. 1 (1966). However, in a recent case involving the civil commitment of a "sexually dangerous person," the same court held that the possibility of a deprivation of liberty requires a measure of due process protection. Although the court stated that full criminal due process ueed not necessarily be superimposed on the civil commitment proceeding, the court seemed to determine the extent of the applicable due process rights by considering the consequences of the proceedings, see text accompanying note 29 supra, rather than by an adherence to the strict civil-criminal dichotomy. People v. Studdard, 51 III. $2 \mathrm{~d}$ 190, 281 N.E.2d 678 (1972). See also People v. English, 31 Ill. 2d 301, 201 N.E.2d 455 (1964) (recognizing that some statements to psychiatrists might incriminate the subject).

64. For an exammation of the history of the privilege, see $8 \mathrm{~J}$. Wromone, supra note $58, \S 2250$.

65. See id. $\$ 2263$, at $378-79$.

66. See Gilbert v. California, 388 U.S. 263 (1967); United States v. Wade, 388

U.S. 218 (1967); Schmerber v. California, 384 U.S. 757 (1966).

67. Schmerber v. Califormia, 384 U.S. 757 (1966).

68. United States v. Dionesio, 410 U.S. 1 (1973).

69. United States v. Mara, 410 U.S. 19 (1973). See also United States v. Wade, 388 U.S. 218 (1967) (requiring suspects to stand in line-ups). 
oral or written confessions. It has been suggested that the results of a mental examination are analogous to those of a physical examination and therefore should be considered "real" evidence. ${ }^{70}$ However, it may also be argued-and this seeins to be the inore logical approach - that such evidence is "testimonial" in nature, since the mental examination attempts to discover the thought processes of the subject, and his often previously unexpressed feelings, through the elicitation of verbal and physical responses. ${ }^{71}$ For several reasons, however, categorizing information obtained as a result of a mental examination as "real" or "testimonial" is not conclusive and should not foreclose fifth amendment inquiry. First, these classifications are somewhat ambiguous. ${ }^{72}$ Second, Wigmore's approach to evidence gathered by police for use in criminal prosecutions should not automatically be extended to an uncharted area of constitutional law. Therefore, attention should instead focus on the meaning and scope which should be given to the privilege within the specific context of the involuntary commitment proceeding. ${ }^{73}$

The issue of whether an individual may assert his privilege agamst self-incrimination by refusing to submit to a psychiatric examination frequently arises in the context of a criminal prosecution in which the defendant affirmatively raises an insanity defense and then attempts to assert his privilege against self-incrimination to avoid the compulsory mental examination. ${ }^{74}$ Somewhat understandably, courts generally turn a deaf ear to such an assertion, ${ }^{75}$ at least where there are adequate statutory protections preventing the use of examination evidence against the defendant during the trial. ${ }^{76}$ Clearly, a distinction inust be drawn

70. See, e.g., Battle v. Cameron, 260 F. Supp. 804, 806 (D.D.C. 1966); Note, Mental Examinations of Defendants Who Plead Insanity: Problems of Self-Incrimination, 40 TEMP. L.Q. 366, 372 (1967).

71. See Note, Requiring a Criminal Defendant 655.

72. Id. at 653-54.

73. Cf. id.

74. See Comment, Changing Standards for Compulsory Mental Examinations, 1969 Wis. L. Rev. 270; Comment, Compulsory Mental Examinations and the Privilege Against Self-Incrimination, 1964 WIS. L. Rev. 671; Note, Requiring a Criminal Defendant 648 ; Note, supra note 70 , at 366 .

75. See, e.g., Battle v. Cameron, 260 F. Supp. 804, 806 (D.D.C. 1966). The court pointed out that it would be an anomaly to allow the defendaut to raise the defense of insanity, thereby placing the burden of proving his samity on the government, and at the same time to deny the prosecution the right to examine the defendant.

76. Cf. 18 U.S.C. $\& 4244$ (1970), which provides in part:

No statement made by the accused in the course of any examination into his sanity or mental competency provided for by this section, whether the examination shall be with or without the consent of the accused, shall be admitted in evidence against the accused ou the issue of guilt in any criminal proceeding. 
between the defendant who is attempting to prevent a mental examination after he has raised the issue of his own sanity, and the individual who asserts the privilege after others have challenged his mental competence. $^{7 \tau}$ If the privilege is to be denied in the context of the involuntary commitment proceeding, it must be for the more fundamental reason that the individual, when subjected to such an examination, is neither in danger of incriminating himself nor likely to lose that core of personal privacy guaranteed by the fifth amendment.

It may be argued that the individual cannot incriminate himself when the aims of the state are beneficent and have treatment rather than punishment as their objective. ${ }^{78}$ Moreover, the fear has been expressed that rigid procedural safeguards-including the availability of the privilege against self-incrimination-may frustrate the commendable goals of the state, and as a consequence inflict harm upon both the individual and society. ${ }^{78}$ Illustrative of this fear is the approach adopted in People v. Fuller, ${ }^{80}$ a recent New York decision upholding the admission of statenients made during the course of an examination of a narcotics addict pursuant to a civil commitment proceeding. The court reasoned that, since the examination is solely for diagnostic purposes, it is "for the addict's benefit, [and] self-incrimination becomes irrelevant."81 Thus, in the Fuller court's view, it is the nonincriminating purpose of the examination which makes the privilege inoperative. ${ }^{82}$ The decision assumes particular significance because it distinguishes Gault as involving a proceeding inherently criminal in nature $^{83}$ and rejects the argument that an examination-even when used

Federal courts do not recognize a defendant's right to remain silent during a psychiatric exammation. See, e.g., United States v. Allbright, 388 F.2d 719 (4th Cir. 1968); Pope v. United States, 372 F.2d 710 (8th Cir. 1967). In state courts, the determinative factor may be the availability of statutory protections preventing the use of the psychiatric testiniony against the defendant in court. See, e.g., State v. Olson, 274 Minn. 225, 143 N.W.2d 69 (1966). For an excellent examination of this issue, see Comment, Changing Standards, supra note 74, at 271-76.

77. Cf. Note, Requiring a Criminal Defendant 668.

78. See notes 19-25 supra and acconpanying text.

79. See notes 19-23 supra and accompanying text.

80. 24 N.Y.2d 292, 248 N.E.2d 17, 300 N.Y.S.2d 102 (1969).

81. Id. at 302,248 N.E.2d at 21,300 N.Y.S.2d at 107.

82. Id. Insofar as the beneficent theory operates, the broader right-of-privacy function of the fifth amendment would likewise be outweighed by the very real state interest in the mental well-being of its citizens. See notes 19-25 supra and accompanying text.

83. Thus, the New York Court of Appeals in Fuller read Gault narrowly as resting primarily on the similarity of the consequences of the juvenile proceeding to those of the adult criminal proceeding. See note 18 supra. The New York court apparently was unwilling to draw the sane conclusion as to the commitment of a narcotics 
solely for diagnostic purposes-must conform to the guidelines set forth in Miranda v. Arizona. ${ }^{84}$

If committed individuals generally received the type of treatment offered by well-staffed medical hospitals, the Fuller court's view that such persons could not invoke the privilege to avoid a mental examination would seein to be well-founded. ${ }^{85}$ But the "beneficient theory of state action" has been largely discredited, leaving in its wake a broad spectrum of judicial and quasi-judicial proceedings to which varying degrees of constitutional protection, including procedural due process, inust be apphed. The purposes underlying the privilege against selfincrimination-the right to remain silent when speech could lead to involuntary confinement closely akin to imprisonment, and the broader right to a zone of personal privacy ${ }^{88}$-strongly indicate that an individual subjected to an involuntary hospitalization proceeding should indeed be entitled to invoke the fifth amendinent against the "testimonial" psychiatric interview.

\section{Practical Problems in Implementation}

Since it would be difficult to ascertain the mental condition of an individual without the aid of an examination, ${ }^{87}$ the availability of the privilege ${ }^{88}$ nay create some obstacles to effective diagnosis. ${ }^{89} \mathrm{Un}$ questionably, the assertion of the privilege against self-incrimination

addict. It is not the deprivation of liberty which is significant under this analysis; rather, it is the penal character of the institutions to which the offenders are sent.

84. 384 U.S. 436, 471-72 (1966). In setting up police interrogation guidelines, the Court stated:

[A]n individual held for interrogation must be clearly informed that he has the right to consult with a lawyer and to have the lawyer with him during interrogation .... As with the warnings of the right to remain silent aud that anything stated can be used in evidence against him, this warning is au absolute prerequisite to interrogation. No amount of circumstantial evidence that the person may have been aware of this right will suffice to stand in its stead. Only through such a warning is there ascertainable assurance that the accused was aware of this rigbt.

85. See, e.g., Wyatt v. Stickney, 325 F. Supp. 781, 784 (M.D. Ala. 1971); People v. Fuller, 24 N.Y.2d 292, 302-03, 248 N.E.2d 17, 21-22, 300 N.Y.S.2d 102, 107-08 (1969).

86. See notes 58-62 supra and accompanying text. One might argue that the need for fifth ameudmeut protection from abusive police interrogation techniques is much greater than the need for protection in less coercive psychiatric interviews. However, since meutal examinations pursuant to involuntary commitunent proceedings force unwilling individuals to reveal their innennost thoughts, the psychiatrist's persistent and manipulative questioning arguably is as reprel1eusible as physical coercion.

87. See notes 49-52 supra and accompanying text.

88. Note that the fifth amendment does not refer to "self-incrimination," but provides only that the accused will not be compelled "to be a witness against himself" (emphasis added). See note 58 supra.

89. See Krash, supra note 51. 
would close off an important avenue of information. ${ }^{00}$ However, obstacles to the ascertainment of truth are the consequence of the exercise of any privilege. ${ }^{91}$ The rationale underlying the fifth amendment is that the values protected by the privilege justify the sacrifice of one avenue for ascertaining the truth. ${ }^{92}$ The Supreme Court gave credence to the broad privacy function of the self-incrimination clause by asserting that the fifth amendment privilege against self-incrimination "is not an adjunct to the ascertainment of truth . . . but stands as a protection of quite different values-values reflecting the concern of our society for the right of each individual to be left alone." 93 Thus, it may be argued that the rationale of the fifth amendment requires that, when an individual may be incarcerated for purposes other than the provision of fully adequate medical treatment, the state may not force him to aid his own incarceration. This conclusion is made even more compelling by the fact that the psychiatric interview, although perhaps the most accurate diagnostic tool available, is also an unparalleled invasion of personal privacy.

The immediate effect of making available the privilege against self-incrimination would be to sharply reduce the role of the medical expert in the involuntary commitment proceeding. While some may, regard this as desirable, the problein arises of finding a satisfactory substitute for the testimony of the medical expert. Currently, the psychiatric examination is the basic diagnostic tool for evaluating the mental condition of an individual; if this is abandoned, nore reliance must be placed upon the testimony of third parties-particularly relatives, friends and co-workers of the individual whose competence is challenged. ${ }^{94}$ An objection may be raised, with some validity, that listen-

90. Even though it has been argued that the objectivity ascribed to the medical expert's conclusions is somewhat exaggerated, see notes 40-46 supra and accompanying text, the psychiatric interview remains the basic diagnostic tool for certain types of mental disorders, see notes 49-51 supra and accompanying text.

91. See C. MCCoRMICK, supra note $59, \S 72$, at 152.

92. Id.

93. Tehan v. United States ex rel. Shott, 382 U.S. 406, 416 (1966).

94. Specifically, testimony of families, friends and co-workers may still provide the basis for an evaluation of the mental health of an imdividual. Furthermore, it is possible in many cases for a psychiatrist to make a diagnosis without actually interviewing the individual. This may be based on long-term observations of the individual or interviews with those who know him well. See Krash, supra note 51, at 918.

It is apparent that the development of alternatives to the compulsory mental examination has been frustrated by the use of the examination itself. "[T]he opportunity to use psychiatric reports is conducive to the state's not seeking independent evidence of the defendant's mental state, through witnesses with whom the defendant voluntarily associated." Note, Requiring a Criminal Defendant 660. See also Rollerson v. United States, 343 F.2d 269 (D.C. Cir. 1964). A classic statement on how direct interroga- 
ing to the testimony of his family and friends to the effect that he should be institutionalized may have a damaging effect on the individual. ${ }^{95}$ However, a more substantial objection can be voiced against the current use of psychiatric testimony. Given the close relationship which must exist between the subject and the medical expert if the psychiatric interview is to be successful, ${ }^{96}$ the subsequent recommendation of the psychiatrist that the subject be committed inay undermine the confidential relationship existing between doctor and patient and thus frustrate subsequent treatment of the individual. ${ }^{97}$

Once it is determined that the privilege against self-incrimination is available, the problein of devising an effective means for enforcing the right reinains. Confronted with a similar problem in Miranda, the Supreme Court established elaborate guidelines requiring that the individual be informed of his right to remain silent and to consult with a lawyer. ${ }^{98}$ Unfortunately, the Miranda solution is not applicable to the

tion techniques operate to forestall the development of sophisticated alternatives, see note 98 infra, was offered by Sir James Stephen: "It is far pleasanter to sit comfortably in the shade rubbing red pepper into a poor devil's eyes than to go about in the hot sun hunting up evidence." J. STEPHEN, A History of the CRIMINal LAW of ENGLAND 442 n.1 (1883).

95. See note 23 supra. If more reliance is placed on the testimony of family and friends, a problem may arise. The family of the individual frequently initiates the proceedings, and to the extent that family members have a strong disposition favoring his commitment, the credibility of their testimony may be questioned. However, family members and friends are not clothed with the mystique of expertise, and a vigorous cross-examination may reveal their predilections.

96. See note 50 supra. The clinical psychologist does not attempt to induce a dependency transference, but rather diagnoses and treats his patients on the basis of thorough behavioral analysis and conditioning techniques. See note 54 supra.

97. This criticism will be mitigated if the testifying expert is not the same psychotherapist who will later be treating the committed patient. On the other hand, a bitter experience in the mental examination may adversely affect any future psychoanalytic relationship with the subject. Furthermore, to the extent that the psychiatric interveiw is itself considered the first step in the treatment process, the therapeutic value of that step has certainly been undermined.

98. 384 U.S. at 479 . See uote 84 supra. The extension of fifth ameudment protection to the "custodial interrogation" has generated a significant amount of criticism based on Miranda's supposed disastrous effect on law enforcement. See, e.g., Ervin, Miranda v. Arizona: A Decision Based on Excessive and Visionary Solicitude for the Accused, 5 AM. CRIM. L.Q. 125 (1967); Miller, Balancing the Rights of the Accused and the Public, 53 A.B.A.J. 1046 (1967). However, subsequent studies have revealed that Miranda's suspected impact was grossly exaggerated, and that indeed there has been little change in conviction rates, the number of guilty pleas, or the disposition of criminal cases. Driver, Confessions and the Social Psychology of Coercion, 82 Harv. L. Rev. 42 (1968); Seeburger \& Wettick, Miranda in Pittsburg-A Statistical Study, 29 U. PrTT. L. Rev. 1 (1967). On the other hand, the fact that Miranda has not had the feared adverse effects may in part be due to the lack of good faith police compliance with Miranda gnidelines. See Project, Interrogations in New Haven: The Impact of Miranda, 76 YALE L.J. 1519, 1550-55, 1571-72, 1613-15 (1967). 
involuntary hospitalization proceeding, for its presupposes that the individual may intelligently waive his rights. Although the individual faced with the danger of involuntary commitment is generally, in the larger sense, presumed to be sane, this presumption should be reversed for purposes of determining whether there has been an intelligent waiver of rights prior to the mental examination. A presumption against waiver would seein to be necessary to fully protect the individual's fifth amendment rights. If such a waiver was determined after the psychiatric interview to have been unintelligently given, a rehearing without admission of the psychiatric interview would protect the individual's interest in not being forced to contribute to his own incarceration. This type of a rehearing could not, however, remedy the irreparable injury inflicted upon the subject's personal privacy by the erroneously permitted psychiatric interview.

This does not inean that an intelligent waiver is impossible, for mental infirmities as a general rule are not completely debilitating. ${ }^{00}$ Many psychotics-manic-depressive personalities, for example-experience transient periods of lucidity during which they may be quite competent to intelligently assess and waive their rights. ${ }^{100}$ Therefore the presumption against the subject's ability to waive the privilege should be rebuttable upon an affirmative showing that the individual involved is competent to understand and waive his rights. Such a procedure would recognize the state's legitimate interest in treating the inentally ill, while securing for the subject of the involuntary civil commitınent proceeding the protection against self-incrimimation and the sphere of personal privacy which the fifth amendinent guarantees.

\section{CONCLUSION}

The application of the fifth amendment to the compulsory psychiatric interview may prove to be a serious bar to involuntary commitment. Whereas problems of proof, the lack of sufficiently developed alternatives, and the lack of judicial expertise in the area of mental health present significant difficulties, these must be balanced against the strong suggestion that medical experts presently inject an excessive

99. See Postel, Civil Commitment: A Functional Analysis, 38 BRookLYN L. Rev. 1,35 (1971). The author notes that "to demand of our commitment laws a definition of 'capacity' in terms which are functionally related to the commitment operation is not to impose upon the law a task which is alien or impossible." Id. at 36.

100. However, since these individuals can usually manage their own affairs, they are committed only when "they become a serious public nuisance." $J$. Coleman, supra note 33, at 313. 
degree of subjectivity into the truth-seeking process. Moreover, aside from practical problems, every individual has a constitutional right not to be "coinpelled in any criminal case to be a witness against himself. . .."101 In the application of due process safeguards, Gault inandates looking beyond the "criminal" or "civil" label to the substance of the proceedings. In this regard, it is clear that many mental institutions have so deteriorated that treatment has becoine inadequate at best, so that lospitalization increasingly resembles imprisonment. Since individuals are typically confined on the basis of their own statements and emotional responses to a skillful psychiatric interrogation, the fifth amendment privilege should be available to protect against self-incrimination and to preserve an inviolate quantum of personal privacy.

101. U.S. Const. amend. V. 
